\title{
Thermomechanical Testing of GGG 40 Spheroidal Graphite Cast Iron Alloy
}

\author{
Marwan Faisal' ${ }^{1}$ Eman El-Shenawy², Mohamed A. Taha1 \\ ${ }^{1}$ Mechanical Design and Production Department, Ain Shams University, Cairo, Egypt \\ ${ }^{2}$ Department of Plastic Deformation, Central Metallurgical R\&D Institute, Cairo, Egypt \\ Email: Marwan.faisal@eng.asu.edu.eg
}

How to cite this paper: Faisal, M. El-Shenawy, E. and Taha, M.A. (2017) Thermomechanical Testing of GGG 40 Spheroidal Graphite Cast Iron Alloy. Materials Sciences and Applications, 8, 273-280. https://doi.org/10.4236/msa.2017.83019

Received: February 24, 2017

Accepted: March 28, 2017

Published: March 31, 2017

Copyright (c) 2017 by authors and Scientific Research Publishing Inc. This work is licensed under the Creative Commons Attribution International License (CC BY 4.0).

http://creativecommons.org/licenses/by/4.0/

\section{cc) (i) Open Access}

\begin{abstract}
Spheroidal graphite cast iron GGG 40 was thermo-mechanically tested using thermo-mechanical simulator Gleeble-3500. Three deformation steps were successively applied on test-specimen at temperatures namely; $900^{\circ} \mathrm{C}, 850^{\circ} \mathrm{C}$ and $750^{\circ} \mathrm{C}$ within the austenitic zone, at the same strain rate of $0.1 \mathrm{~s}^{-1}$. No cracks were observed, up to $50 \%$ deformation, after successive deformation steps. Stress-strain relationship obtained is correlated with previous work on SGCI with a different carbon equivalent. It was found that by decreasing the deformation temperature; for the same $\mathrm{CE}$, young's modulus, yield strength and strain hardening exponent increase. Microstructure of the deformed zone, for a specimen quenched after the final deformation step, reveals fine elongated ferrite and pearlite, as well as elongated graphite. While microstructure of the non-deformed zone subjected to the same treatment, includes coarser ferrite and pearlite with graphite spheres embedded in the matrix.
\end{abstract}

\section{Keywords}

Thermo-Mechanical Behavior, Spheroidal Graphite Cast Iron, Gleeble-3500

\section{Introduction}

Spheroidal graphite cast iron (SGCI) is an iron-carbon alloy, in which the structure is composed of graphite nodules embedded in a steel matrix [1]. It is characterized by mechanical properties, such as strength and ductility, which are equivalent to those of steel. In addition to its high cast-ability and with lower manufacturing cost compared to steel alloys, SGCI is widely used in automotive industry such as crankshafts and bearing journals, due to excellent wear resistance [2] [3] [4] [5]. Production of sheets of SGCI seems to be very interesting, due to the unique properties that SGCI exhibit, namely; low thermal expansion, damping characteristics and wear resistance. This will also allow massive con- 
tinuous processing of the material suitable for many constructional applications.

In spite of the high ductility of SGCI, the study of its workability to form sheets through rolling process is rare. Mrzygłód studied the effect of heat treatment parameters on the microstructure of SGCI containing $\mathrm{Ni}, \mathrm{Mo}$ and $\mathrm{Cu}$. $\mathrm{He}$ plotted the TTT and CCT diagrams of SGCI with carbon equivalent of 4.42 [6]. Nabil Fatahalla investigated the effect of varying carbon equivalent on the microstructure and mechanical properties of austenitic ductile iron. A slight decrease in the hardness and the tensile strength was observed, while the ductility increased with the increase of the carbon equivalent [7]. In the literature, the deformation behavior of spheroidal graphite cast iron was considered for a study by Zhao [8] [9] [10] through applying severe plastic deformation process, In another work by Kai Qi [11] the hot deformation behavior of ductile iron on Gleeble 1500 physical simulator at range of temperatures between $600^{\circ} \mathrm{C}$ and $950^{\circ} \mathrm{C}$ with high strain rate of $10 \mathrm{~s}^{-1}$ was investigated. The aim of his work is to investigate the workability of SGCI at high strain rate. Furthermore, K. Le Mercier [12] studied the thermo-mechanical behavior of ductile iron GGG 70 at high temperature namely $800^{\circ} \mathrm{C}$ and $1000^{\circ} \mathrm{C}$. He focused on determining the dynamic recrystallization at the elevated temperatures. Chengchang Ji and Shigen Zhu designed a SGCI alloy and investigated its formability. They carried out Rolling experiments from bar to plate, and from bar to bar. They found that during the rolling of plate, the one pass compression ratio and the total compression ratio are up to 1.39 and 3.90, respectively. In the course of rolling of bar, the total section compression ratio is up to 4.47 [13].

The current work presents some experimental results on thermo-mechanical testing of SGCI GGG 40 with Carbon Equivalence (CE) of 4.6, using thermo-mechanical simulator. Gleeble-3500 instrument was used, where successive compression at different temperatures was applied. This was to study the effect of deformation on phase transformation and graphite morphology during the deformation process. The data obtained from the dilation experiments would be useful for simulating the rolling process having successive stands.

\section{Experimental Procedures}

The chemical composition of SGCI grade GGG40 used in this work, is shown in Table 1. The experiments were carried out on a computer servo-controlled Gleeble-3500 machine. In accordance to this instrument, cylindrical specimens of SGCI, with $10 \mathrm{~mm}$ in diameter and $120 \mathrm{~mm}$ in height, as shown in Figure 1, were machined from $12 \mathrm{~mm}$ in diameter bar. Both ends of the specimen were screwed with M10 standard screw for $15.25 \mathrm{~mm}$, for fixing in to threaded grips. For measuring the temperature, K-type thermocouple wire, $2 \mathrm{~mm}$ in diameter, was spot-welded in the middle of the specimen in order to control its temperature. Controlled heating-cooling cycle was applied on the round bar specimen for dilatation purpose. Dilatations accompanying heating or cooling temperatures are recorded and graphically presented. 
Table 1. Chemical composition of SGCI.

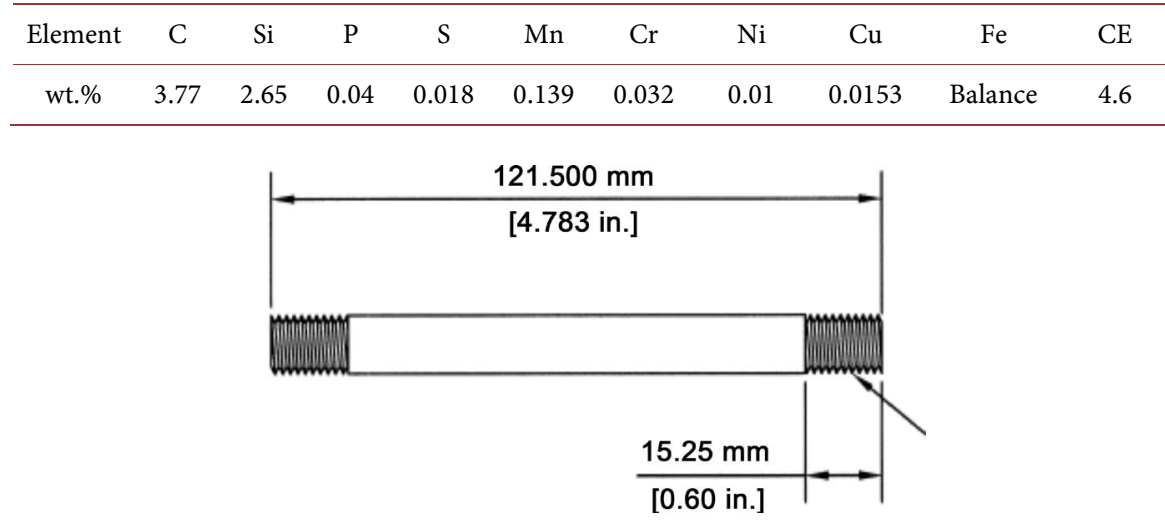

Figure 1. Gleeble test specimen for dilation investigation.

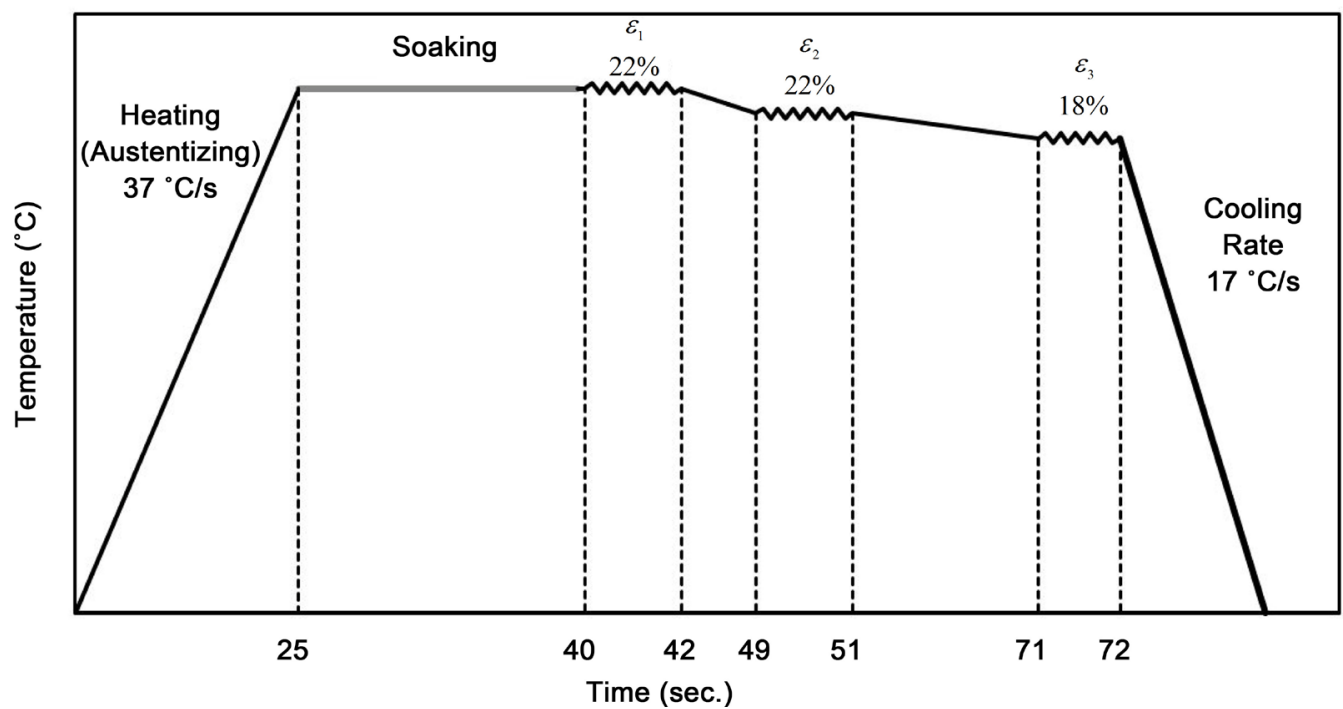

Figure 2. Schematic presentation of 3-consecutive deformation hits executed on thermo-mechanical simulator (Gleeble 3500).

Two types of experiments were applied on the mentioned SGCI. The first experiment was to indicate the austenite zone by the aid of dilation test. A specimen was heated to $900^{\circ} \mathrm{C}$ with rate of $92.5^{\circ} \mathrm{C} / \mathrm{min}$ followed by holding for 25 seconds at the same temperature, afterward it was finally cooled with a rate of 82 ${ }^{\circ} \mathrm{C} / \mathrm{min}$. The second experiment involves three pass hot rolling process was physically simulated on the thermo-mechanical simulator (Gleeble 3500). It was conducted at 3 different deformation temperatures within the austenite zone, which are $900^{\circ} \mathrm{C}, 850^{\circ} \mathrm{C}$ and $750^{\circ} \mathrm{C}$, as shown in Figure 2. First, the specimen was heated to the deformation temperature of $900^{\circ} \mathrm{C}$ with a heating rate of $37^{\circ} \mathrm{C} / \mathrm{sec}$ then soaked for 15 seconds, afterward uni-axial compression of -0.25 true strain was applied with strain rate of $0.1 \mathrm{~s}^{-1}$. After that the specimen was cooled to $850^{\circ} \mathrm{C}$ and the second deformation step was involved where another compression of -0.25 true strain with the same strain rate was applied. Finally, the third deformation step was involved after cooling the specimen to $750^{\circ} \mathrm{C}$ to apply the last compression with -0.2 true strain. 


\section{Results and Discussion}

\subsection{The Austenite Zone}

The first experiment is useful for conducting the dilation test at temperatures and after cooling times within the austenite zone. The expansion and contraction in the specimen length (change in length)-temperature obtained from heating and cooling the specimen respectively is shown in Figure 3. Upon heating the specimen to $900^{\circ} \mathrm{C}$, the length increases to record a change in length of $0.414 \mathrm{~mm}$. While upon cooling the specimen, the length decreases again with slight inclination at $758^{\circ} \mathrm{C}$, indicating the start of ferrite phase transformation. The start of ferrite phase transformation is indicated in the (change in length temperature) curve, when the austenite phase (FCC structure) transform to ferrite phase (BCC structure) recording an increase in length as the FCC structure is more closed packed than the BCC structure. Thus, the ferrite transformation starts below $758^{\circ} \mathrm{C}$.

The experimental cooling curve is imposed on the TTT curve reported for a previous work on SGCI with $\mathrm{CE}=4.27$ [14] as shown in Figure 4. This curve intersects the ferritic transformation $C$ limit curve [14] at a temperature of $755^{\circ} \mathrm{C}$ and a time of 96.5 seconds. Therefore, the TTT diagram of the previous work [14] would be considered for the present work.

\subsection{Deformation Behavior}

In Figure 5, the cooling curve of the sample while subjected to successive compression is imposed on the $\mathrm{C}$ diagram. Successive deformation steps are at 3 different temperatures of $900^{\circ} \mathrm{C}, 850^{\circ} \mathrm{C}$ and $750^{\circ} \mathrm{C}$. As indicated in the figure all deformation steps have been accomplished with in the austenite zone.

The stress-strain curve of SGCI $(\mathrm{CE}=4.6)$ with applied strain rate of $0.1 \mathrm{~s}^{-1}$ at the deformation temperatures used, is shown in Figure 6. No macroscopic cracks were observed in the specimen after successive compression. As given in Table 2, with decreasing the deformation temperature; young's modulus, yield

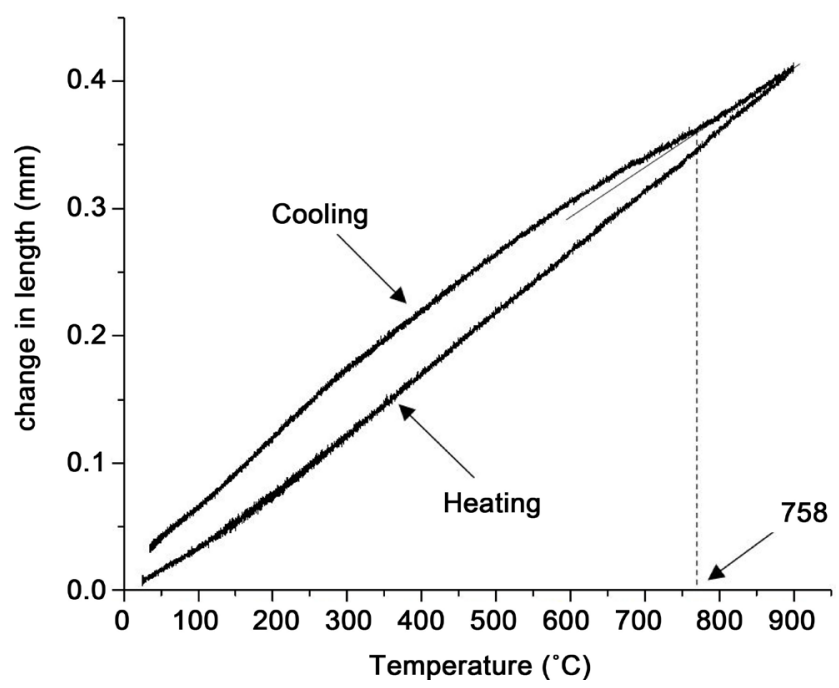

Figure 3. Dilation test: Change in length-Temperature curve. 


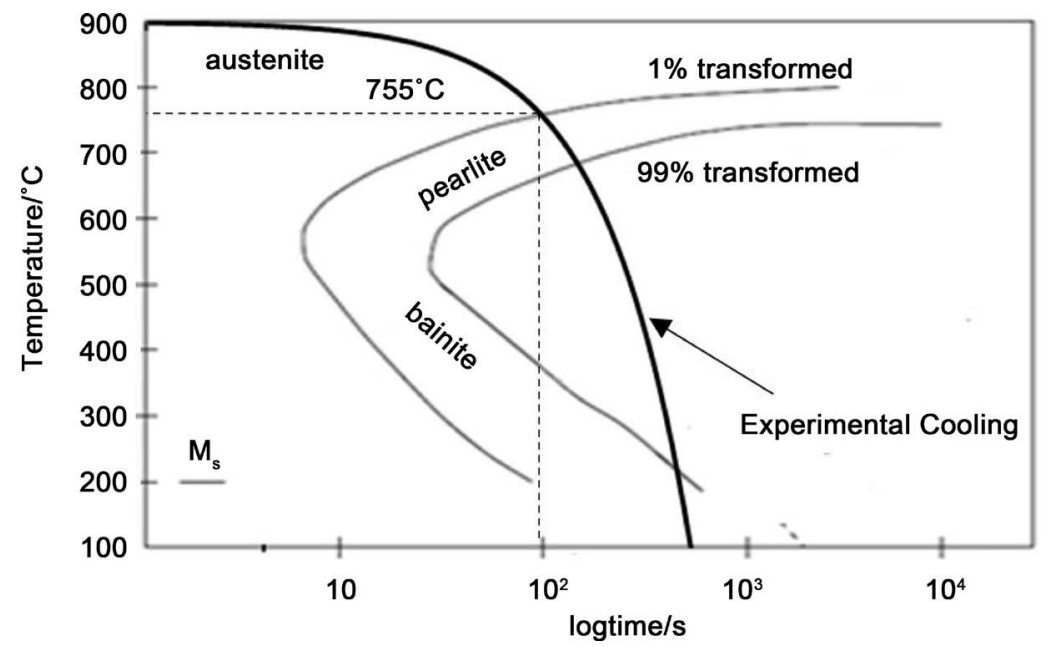

Figure 4. The cooling curve of sample SGCI with $\mathrm{CE}=4.6$, imposed on the TTT curve [14] of $\mathrm{CE}=4.27$.

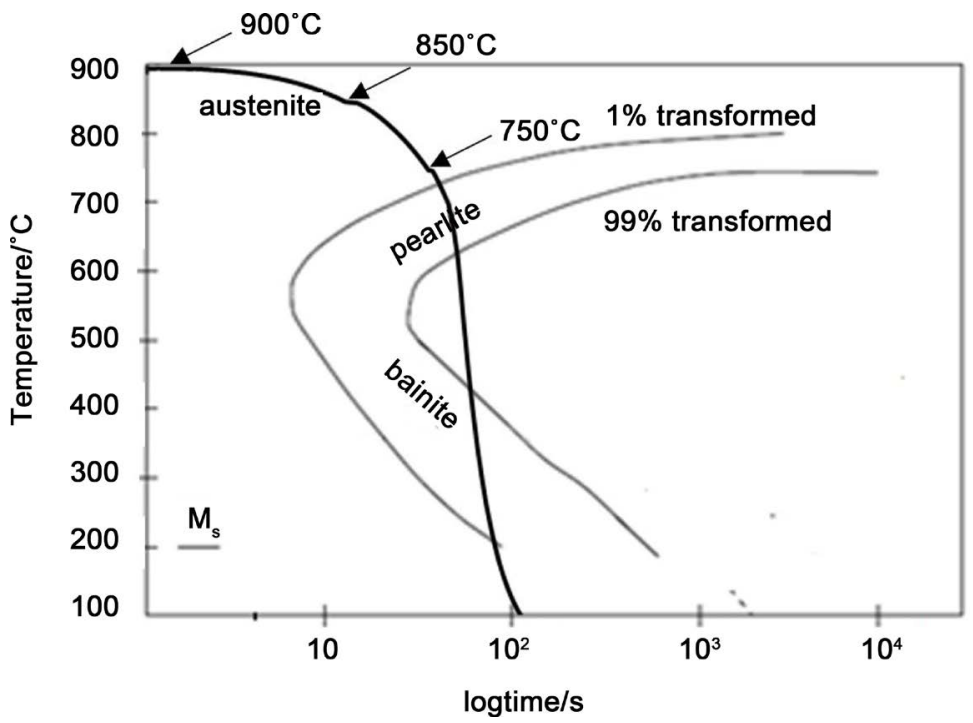

Figure 5. Thermo-mechanical deformed cycle.

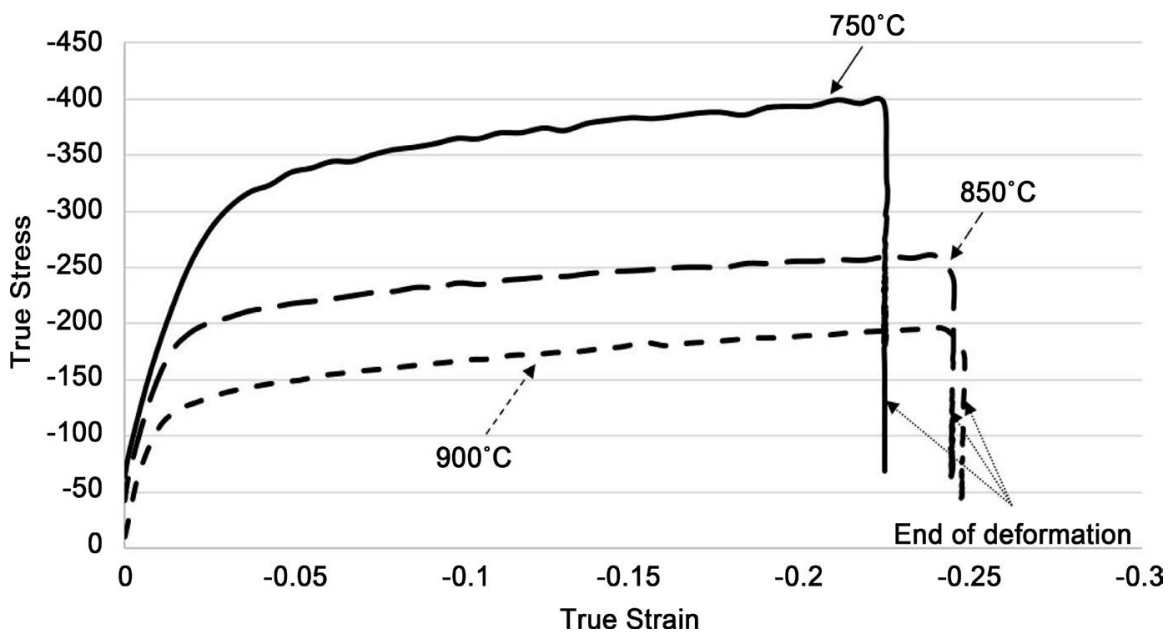

Figure 6. Thermo-mechanical deformed cycle Stress-strain curves of SGCI $(\mathrm{CE}=4.6)$ at deformation temperatures of $900^{\circ} \mathrm{C}, 850^{\circ} \mathrm{C}$ and $750^{\circ} \mathrm{C}$. 
Table 2. Mechaniacl properties of SGCI $(\mathrm{CE}=4.6)$ alloy at different deformation temperatures.

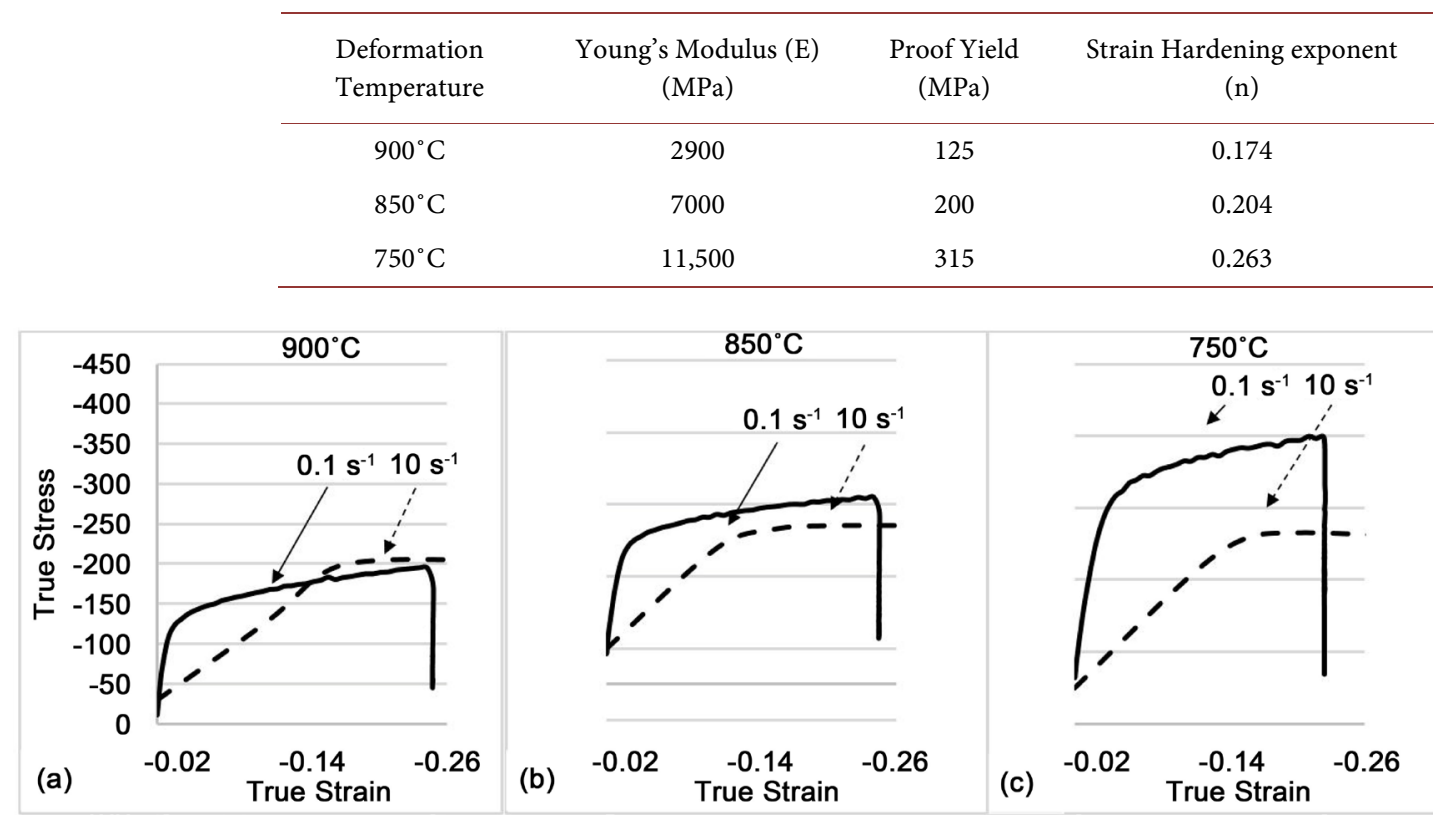

Figure 7. Effect of deformation on stress strain diagram obtained in present $\left(0.1 \mathrm{~s}^{-1}\right)$ and previous $\left(10 \mathrm{~s}^{-1}\right)$ work [11]: (a) at $900^{\circ} \mathrm{C}$-both 1 step deformation, (b) at $850^{\circ} \mathrm{C}$-present (2nd step), previous (1 step), (c) at $750^{\circ} \mathrm{C}$-present (3rd step), previous (1 step).

strength and strain hardening exponent increases. The deformation of austenite phase at lower temperatures becomes harder as the energy required for the phase to deform decreases i.e. the energy required for atomic planes to slip and dislocations movement decreases.

Kai Qi [11] studied the hot deformation behavior of SGCI $(\mathrm{CE}=4.8)$ at similar deformation temperatures: $900^{\circ} \mathrm{C}, 850^{\circ} \mathrm{C}$ and $750^{\circ} \mathrm{C}$. Specimens of $8 \mathrm{~mm}$ in diameter and $15 \mathrm{~mm}$ in height were heated to the stated deformation temperatures, soaked for 180 seconds and followed by single deformation at high constant strain rate of $10 \mathrm{~s}^{-1}$ using Gleeble-1500 simulator.

Figure 7 shows a comparison between the present work on successive deformation and the single deformation behavior of Kai Qi. In both cases of single deformation at $900^{\circ} \mathrm{C}$, Figure $7(\mathrm{a})$, stress-strain diagrams are almost close to each other. With successive deformation at $850^{\circ} \mathrm{C}$ and $750^{\circ} \mathrm{C}$ by applying $2 \mathrm{nd}$ step and 3rd step deformation respectively, Figure 7 (b) and Figure $7(\mathrm{c})$, resulted in remarkable increase in young's modulus, proof yield and strain hardening. While in case of single deformation at the same temperatures, only slight increase in their values is observed.

\subsection{Microstructure Observation}

The microstructure after applying the three successive deformations at $900^{\circ} \mathrm{C}$, $850^{\circ} \mathrm{C}$ and $750^{\circ} \mathrm{C}$ successively followed by quenching, is observed in the middle of the deformation zone. This is compared to the microstructure of a part in the specimen far from deformation zone within the treated region, Figure 8. 


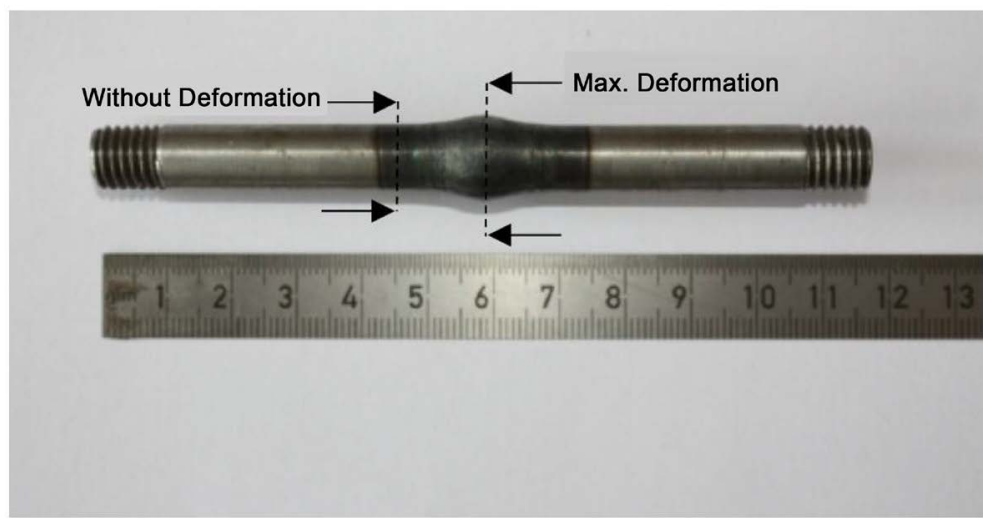

Figure 8. Gleeble test specimen after deformation.
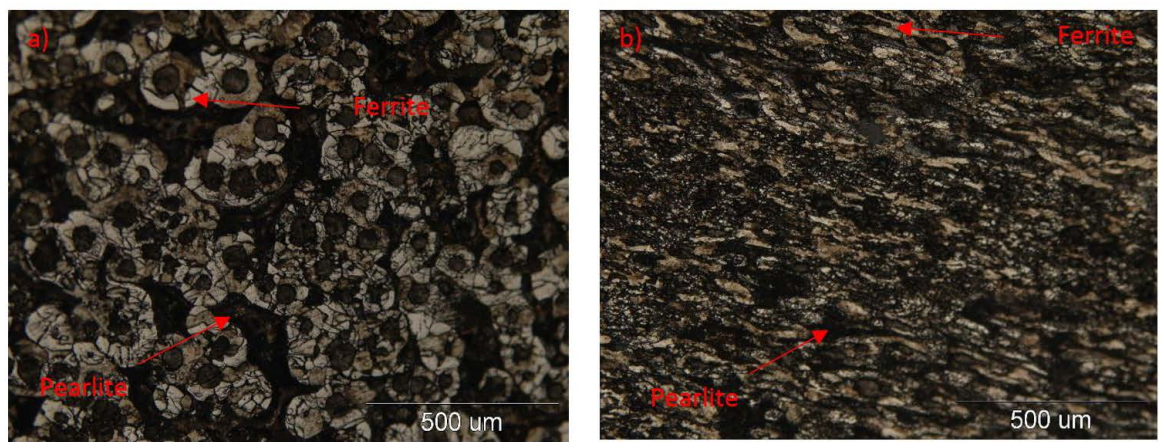

Figure 9. (a) Heat Treated specimen without deformation, (b) Thermo-mechanical Treated specimen.

Figure 9, shows two photomicrographs of specimens; a-without deformation and $\mathrm{b}$-with deformation. Without deformation, Figure 9(a) shows a coarse ferrite phase surrounding the graphite spherical nodules, while the pearlite is observed as the matrix. In principal, transforming the austenite phase to the ferrite phase lead to the carbon in the supersaturated solid solution (austenite) diffusing to the graphite nodules, leaving the matrix without carbon to form ferrite. While the other carbon that didn't have enough energy to diffuse to the graphite nodules resulted in pearlite formation (cementite and eutectoid ferrite).

After the three successive deformation, Figure 9(b) shows much finer elongated structure composed of fine ferrite surrounding elongated graphite, while the pearlite phase represents the matrix. Thus, the influence of deformation is such that it results in refining and elongation of formed phases and graphite nodule. As observed in Figure 9(b), the ferrite grains, which became fine and elongated, increased in number. The elongated graphite after deformation has been also reported in a previous work [11].

\section{Conclusions}

- SGCI was successively deformed, in three deformation temperature steps at elevated temperatures in austenitic zone namely; $900^{\circ} \mathrm{C}, 850^{\circ} \mathrm{C}$ and $750^{\circ} \mathrm{C}$, up to $50 \%$ deformation with no macro or micro cracks observed.

- Each deformation temperature step resulted in an increase in stress and 
strain hardening values compared to the preceding deformation temperature.

- Microstructure observation of successively deformed SGCI at the stated temperatures revealed the formation of a finer elongated structure of ferrite and pearlite, as well as elongated graphite.

\section{References}

[1] Messler, R.W. (2004) Joining of Materials and Structures: From Pragmatic Process to Enabling Technology. Elsevier.

[2] Sheng, D. and Liu, J. (2000) Cast Irons Containing Rare Earths. Tsinghua University.

[3] Sidjanin, L., Smallman, R. and Young, J. (1994) Electron Microstructure and Mechanical Properties of Silicon and Aluminium Ductile Irons. Acta Metallurgica et Materialia, 42, 3149-3156. https://doi.org/10.1016/0956-7151(94)90412-X

[4] Cho, G., et al. (2007) Effects of Alloying Elements on the Microstructures and Mechanical Properties of Heavy Section Ductile Cast Iron. Journal of Materials Science \& Technology: English Edition, 23, 97-101.

[5] Ghaderi, A., Ahmadabadi, M.N. and Ghasemi, H. (2003) Effect of Graphite Morphologies on the Tribological Behavior of Austempered Cast Iron. Wear, 255, 410-416. https://doi.org/10.1016/S0043-1648(03)00156-X

[6] Mrzygłód, B., et al. (2015) Effect of Heat Treatment Parameters on the Formation of ADI Microstructure with Additions of Ni, Cu, Mo. Archives of Metallurgy and Materials, 60, 1941-1948. https://doi.org/10.1515/amm-2015-0330

[7] Fatahalla, N., Abuelezz, A. and Semeida, M. (2009) C, Si and Ni as Alloying Elements to Vary Carbon Equivalent of Austenitic Ductile Cast Iron: Microstructure and Mechanical Properties. Materials Science and Engineering: A, 504, 81-89.

[8] Wang, W., et al. (2007) Properties of a Gray Cast Iron with Oriented Graphite Flakes. Journal of Materials Processing Technology, 182, 593-597. https://doi.org/10.1016/j.jmatprotec.2006.09.028

[9] Zhao, X., et al. (2004) A New SPD Process for Spheroidal Cast Iron. Materials Letters, 58, 2335-2339. https://doi.org/10.1016/j.matlet.2004.01.034

[10] Zhao, X., et al. (2004) Morphology of Graphite in Hot-Compressed Nodular Iron. Journal of Materials Science, 39, 6093-6096. https://doi.org/10.1023/B:JMSC.0000041709.60100.56

[11] Qi, K., et al. (2009) Research on the Hot Deformation Behavior and Graphite Morphology of Spheroidal Graphite Cast Iron at High Strain Rate. Materials \& Design, 30, 4511-4515. https://doi.org/10.1016/j.matdes.2009.05.019

[12] Le Mercier, K., et al. (2013) Thermo-Mechanical Behaviour of Spheroidal Graphite Iron in the Austenitic Phase. In: Congrès Français de Mécanique (21; 2013; Bordeaux).

[13] Ji, C. and Zhu, S. (2006) Study of a New Type Ductile Iron for Rolling: Deformation tests (2). Materials Science and Engineering: A, 419, 326-330. https://doi.org/10.1016/j.msea.2006.01.018

[14] Gonzalez, M.A.Y. (2001) Modelling the Properties of Austempered Ductile Cast Iron. Diss. Ph.D. Thesis, University of Cambridge, England. 
Submit or recommend next manuscript to SCIRP and we will provide best service for you:

Accepting pre-submission inquiries through Email, Facebook, LinkedIn, Twitter, etc. A wide selection of journals (inclusive of 9 subjects, more than 200 journals)

Providing 24-hour high-quality service

User-friendly online submission system

Fair and swift peer-review system

Efficient typesetting and proofreading procedure

Display of the result of downloads and visits, as well as the number of cited articles Maximum dissemination of your research work

Submit your manuscript at: http://papersubmission.scirp.org/

Or contact msa@scirp.org 